\title{
Promoting Croatian Tourism Promotion through Diplomacy
}

\author{
Marija Jović Pešut Dr. Sc., Director of City Library "Don Mihovil Pavlinović,,Kralja \\ Zvonimira 1, Imotski \\ Memnun Zečić Dr. Sc., Faculty of Social Sciences, Dr Milenka Brkića University of \\ Herzegovina, Kraljice Mira 3A, Bijakovići
}

\begin{abstract}
SUMMARY
Tourism is an inevitable segment of the economy. Especially in today's crisis. Specifically, in the Republic of Croatia, more and more information TV shows claim that how much is expected from this year's tourist season in order to save the state budget from tourism revenues. One does not have to be too big an expert to go through the Adriatic coast, noticing how much tourism as an economic-cultural branch has advanced. In previous times, what a tourist would get was a beautiful sea, accommodation, good but traditional food. And that would be pretty basically everything. By developing science and culture and realizing globalization in the true sense of the word, service providers or tour operators generally have solidified with the upcoming trends. Today, in addition to the well-preserved sea and nature, and by adapting to the need and importance of the fast pace of economic development, guests are offered a variety of services.
\end{abstract}

Keywords: Tourism, diplomacy, diplomats, multiculturalism, cooperation, strategy.

\section{INTRODUCTION}

When talking about diplomatic strategy of tourism of countries with a scientific approach, it is necessary to emphasize that we cannot solve this without scientific analysis and application of scientific methods. The approach of diplomatic strategy from the Republic of Dubrovnik and from today's modern states, of which Dubrovnik was part, also requires an understanding of the relationship between the general and special factors that make up today's diplomacy. The ignorance and misunderstanding of peoples, different living conditions, levels of education and literacy, reflected the availability of information that was supposed to contribute to better education.

We therefore tried to provide a more comprehensive picture of the Republic of Dubrovnik and its diplomacy, and hence its influence on contemporary diplomacy, based on available sources, primarily through the analysis of documents found in the Ministry of Foreign Affairs, Ministry of Tourism, available documents from the State Archives of Dubrovnik and other available literature. Furthermore, we also wanted to see the role of contemporary tourism diplomats using this data.

Certainly, communication of diplomats and tour operators is important here, who, by gathering relevant information on the ground, need to inform in a timely manner all those involved in the country's tourism so that the next season can be better prepared. The first step is primarily Dubrovnik, which has for several years, going back to the beginning of the story, when the City was governed by the Senate, the Great and Little Council ... opened its doors to diplomatic activities, through which it promotes the country in a tourist sense even today.

Therefore, as an example of a regulated space in all segments, and also in the segment of the genetic heritage of the diplomatic approach, all the most important events in the Republic of Croatia of international character, organized by national diplomacy, take place in "Under the city of Srđ" (Berković 2009, Harris 2006). By arriving in Dubrovnik, we are sending a fascinating message to the world. And that means that Dubrovnik is present today as the world's top destination in all the leading national tourist brochures. In this way, the other Croatian regions and cities have maybe been neglected. For now, it seems that Croatian tourist workers in diplomatic endeavours seem to be playing it safe. How true this is, time will tell.

\section{MULTICULTURISM AS AN ADVANTAGE}

Some areas should be promoted in such a way that emphasis is given to multiculturalism. After the Homeland War though, it was difficult to go in that direction. However, with stabilization and by setting up the opportunities and restoring Croatian regions within the framework of the Croatian legal system, today it would be possible to talk about such forms of tourism that would in the first place contribute to the particularities of tourist offers and ultimately to make money and activate the economy through such a form of tourism. This also means that tourism, the media, and especially diplomacy, 
dealing with other and different people, cultures, religions, states, races and philosophies, should remember the stories of Dubrovnik and the inscription "Ignoto deo." Different cultures; if this difference is designed in the right way, it can be a great advantage. Tourists visiting various parts of the world, refreshed with new knowledge, bring this information back to their own country and are actually "extended diplomats" themselves, helping to spread visibility to others about a particular country. In that sense it can be said that the rhythm of cultural elements travelling can "be compared with the waves that arise when a stone falls into the water. They touch the closest points first and then distance them gradually. The nearest neighbours take over the cultural elements first and, over time, hand them over to their neighbours." (Erlich, 1968). If this practice were to occur, tourism in cooperation with diplomacy would be the main driver of economic development. Of course, taking into account contemporary globalization processes: "Speaking of globalization today, it seems completely natural and certainly opportune, no matter what area of human life is concerns. [...] Therefore, it would be absurd to discuss world tourism in the current circumstances, especially about tourism in the future, in the way and from the scientific point of a period where the globalization processes did not yet begin "(Vukonić, 2010).

\subsection{Position of tourist products of the Republic of Croatia}

The answer to the question, with which we wanted to demonstrate and prove the claim of the imperative role of diplomacy, which promotes the country in the world, whether in a diplomatic opinion the tourist product of the Republic of Croatia was properly put into practice - most responded negatively. The reasons for negative advertising are explained by imprecision, the lack of short-term and long-term goals and too many different offers. Tourists, in the opinion of many diplomats, still do not yet perceive the country for a certain product, and this should definitely be present.

Table 1. Has the tourist product of the Republic of Croatia been properly set up in practice?

\begin{tabular}{l|llll|} 
& Frequency & Percentage & $\begin{array}{l}\text { Percentage of } \\
\text { valid }\end{array}$ & $\begin{array}{l}\text { Cumulative } \\
\text { percentage }\end{array}$ \\
YES & 25 & 48,1 & 48,1 & 48,1 \\
NO & 27 & 51,9 & 51,9 & 100,0 \\
Everything & 52 & 100,0 & 100,0 &
\end{tabular}

Source: Data obtained by questionnaire

Graph 1. Is the tourist product of the Republic of Croatia properly set up in practice?

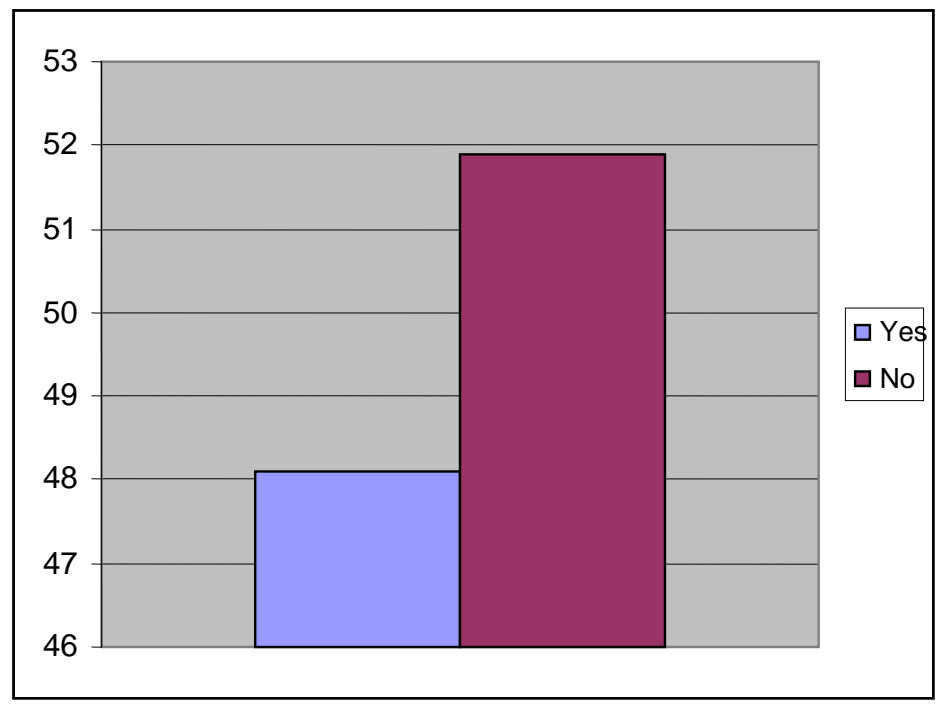

Most competent people think that positive moves have been made and efforts have likely been made towards the development of tourist products, but the diplomats assessing the situation in the field in the countries in which they operate believe that many items are not yet put in place completely. The reasons are explained in the following graph/table example;

Table 2. The reasons for the negative position of the tourist product 


\begin{tabular}{|c|c|c|c|c|}
\hline & Frequency & Percentage & $\begin{array}{l}\text { Percentage of } \\
\text { valid }\end{array}$ & $\begin{array}{l}\text { Cumulative } \\
\text { percentage }\end{array}$ \\
\hline Incomplete & 32 & 61,5 & 61,5 & 61,5 \\
\hline $\begin{array}{l}\text { There are no short-term and } \\
\text { long-term goals that are } \\
\text { based on the } \\
\text { recommendations of } \\
\text { scientific research }\end{array}$ & 10 & 19,2 & 19,2 & 19,2 \\
\hline Too many various offers & 10 & 19,2 & 19,2 & 100,0 \\
\hline Everything & 52 & 100,0 & 100,0 & \\
\hline
\end{tabular}

Source: Data obtained by questionnaire

Graph 2. The reasons for the negative position of the tourist product

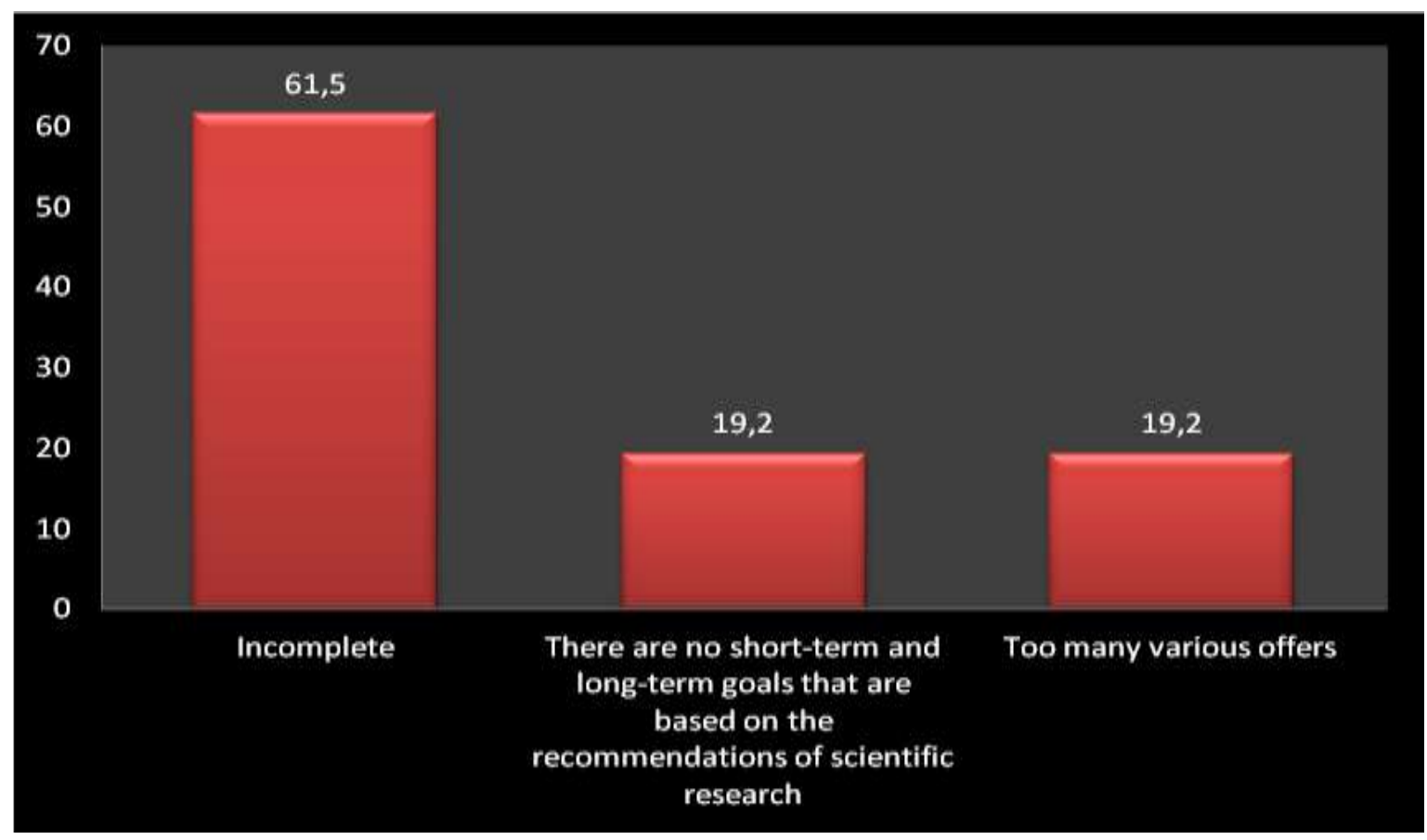

It is therefore necessary to be well informed and have a vision. Otherwise, the advantages a particular country has, in the absence of a vision, can in fact be only a burden.

\section{COMPETITIVENESS ON THE INTERNATIONAL MARKET OF INVESTMENT CAPITAL}

The current situation in Croatian tourism evidently requires a flow of fresh capital. Foreign investment in tourism, other than directly contributing to the development of tourism offers, has a highly positive indirect impact on other areas of the economy that would otherwise be missing or would come back much later.

In addition, Croatia is in the process of market transformation and the growth of foreign exchange inflows from tourism represents a significant aspect of the country's financial policy. Croatia has to seriously understand the basic reason for the lack of direct foreign investment in tourism, and that is an unsatisfactory rate of return on the investment. Today's tourists do not just want to enjoy hedonism in particular destinations, but they also want to get acquainted with the cultural heritage of the countries in which they are spending their time, which diplomacy must certainly take into account.

Table 3. Are diplomats acquainted with the "Main Plan and Tourism Development Strategy of the Republic of Croatia by 2020 ?"

Frequency Percentage Percentage of valid Cumulative

www.ijera.com DOI: 10.9790/9622-0707041621 $\quad \mathbf{1 8}$ |P a g e




\begin{tabular}{|c|c|c|c|c|}
\hline YES & 27 & 51,9 & 51,9 & $\begin{array}{l}\text { percentage } \\
51,9\end{array}$ \\
\hline NO & 25 & 48,1 & 48,1 & 100,0 \\
\hline Everything & 52 & 100,0 & 100,0 & \\
\hline
\end{tabular}

Source: Data obtained by questionnaire

Graph 3. Are diplomats acquainted with the "Main Plan and Tourism Development Strategy of the Republic of Croatia by $2020 ? "$

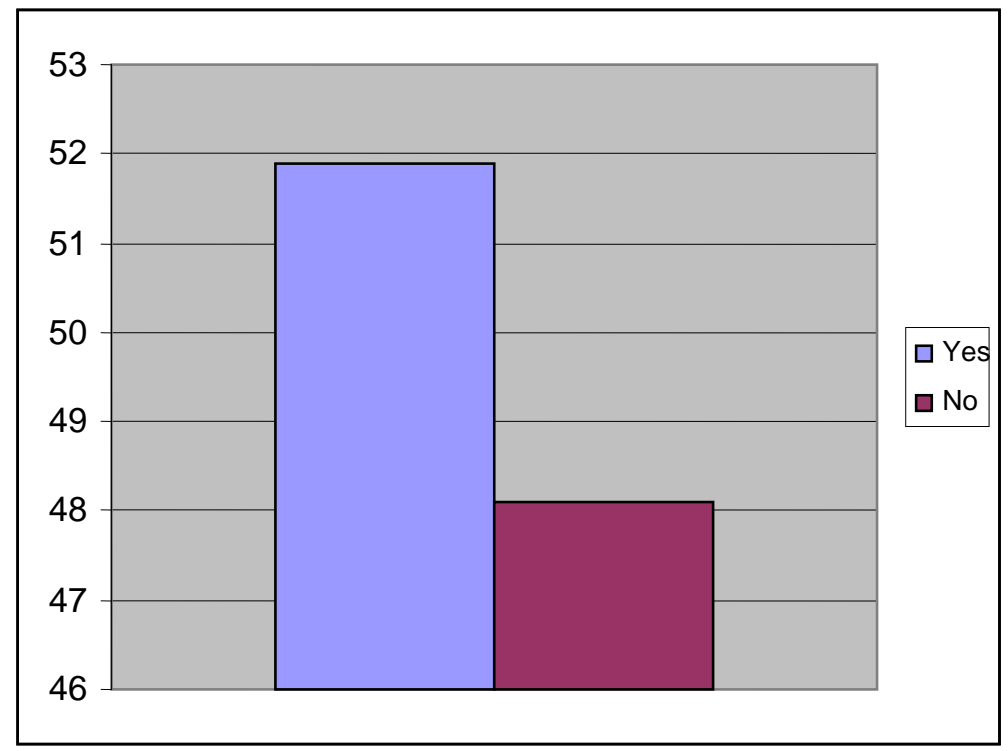

With the results of the questionnaire, we have come to the conclusion that diplomats are not fully acquainted with the mentioned plan. In that sense mistakes have been made, and work should certainly be done on introducing diplomacy to main strategic tourist documents in the future. Diplomats do not fully know any other documents that treats the tourist product. Diplomacy in a limited sense can directly assist Croatian tourism, mainly through a political promotion approach to this topic. Field information is certainly welcome. Author Rob Kroes in the article Tourism and Cold War Diplomacy, among other things, writes about the importance of historical heritage for a country's tourism promotion. Kroes writes that even Cold War diplomacy should not be neglected as part of the history of individual countries (Kroes, 2010, pp. 563).

Christopher Endy decided to give different views of transatlantic tourism in the Cold War years. $\mathrm{He}$ courageously presented an attempt to put importance in an unfairly neglected field of foreign policy and international relations[...] (Kroes, 2010

\subsection{Targeted incentive policy}

In order to create an environment suitable for the growth of direct capital investments in tourism, obstacles must be removed in order to achieve the required return on investment. There are concrete measures and efforts that need to be taken to create a competitive position on the international capital market. It has been proven that a targeted incentive policy has an impact on the growth of direct foreign investments in tourism. In this sense, the following measures are proposed:

- Ensure legal framework and investment security for all investors, domestic and foreign, and to intensify efficient and quality support with direct investments in tourism.

- To fully equalize the legal status of domestic and foreign investors, and to apply the same criteria in practice.

- Declare tourism and attract foreign investments as a decision made at the highest political level, and ensure its implementation in practice, or to intensify the financial, fiscal and organizational engagement of the state.

- As in the process of privatization, it is necessary to conduct quality marketing towards potential investors.

- Enable tax incentives in tourism, which has proved to have a major impact on intensifying foreign investment.

- Intensive cooperation of the public and private sector which need to be stimulated and stimulated by the state. Such a way of investing in tourism has proven to be efficient long-term because it meets both private and state initiatives and has positive financial and ecological aspects.

- Support plans and subsidies must be in line with existing spatial plans and master plans so that 
investments are consistent with the planned development of tourism in the destination, and are very clear and transparent in their terms.

- Adequate presentation of stimulating measures and positive factors essential for potential investors. As with the privatization process, marketing is a very important component of stimulating investment.

- The policy of the labour force demands stimulating measures to meet the needs for quality and a workforce that is not too expensive, and on the other hand, to make tourism attractive to young people (www.mint.hr, 2011).

Numerous authors are involved in meeting the above mentioned items in a different form. Knowing the culture of a particular country that is being visited is of particular importance. And this is best achieved by visiting a country where diplomacy should work to attract as many foreigners as possible in order to know the country in a different way than the media.

Foreigners, especially Western Europeans and Americans, "discovered" Spain because of tourism. Many strangers have learned that political and social conditions in Spain are not what they have believed so far. They were sure it was a free country, and people were better than they imagined. In other words, their improved impression of Spain was the result of their visit. Over time, the cumulative effect of such representations can be reflected significantly in print and the authorities of the countries they came from (Rosendorf, 2009).

Croatia must persistently seek solutions in three aspects;

How do others see us?

Who are our allies?

What are we known for? (Jović, 2011).

"Therefore, Croatian representatives in various integration organizations and bodies that consider the issues of unification at the level of Europe, should undoubtedly represent legitimate interests" (Vlahović, 2003).

When the world is acquainted with Croatian cultural and spiritual wealth, by getting to know the area, it will make it easier to understand how this country is not a satellite of Europe that is yet to be connected. If things develop favourably, Croatia could soon become an interesting and desirable member of the world community. Changing the way of life, shaped by the urbanization process that followed the literacy process, was a reflection of new standards. Scientific discoveries went further. It was precisely about the essence of modernity and about the actual change of priorities.

\section{CONCLUSION}

In the future, the coordinated communication between the mentioned links diplomacy and tourism - should be focused on the spread of views and other places that we would then present as targeted special tourist destinations. Measurements influenced three important factors: 1) The importance of the positive promotion of an own country in the world, 2) The attitude of the citizens of other countries towards Croatian destinations, 3) The general beliefs on the quality of Croatia in the cultural and historical aspect from the level of tourists. We then made a step forward and adjusted this questionnaire and applied it to a sample of Croatian diplomats in the world. The presence and interest of Croatian diplomats was measured by the positive promotion of their own country. Already in the next question of whether diplomats are familiar with the main strategic documents for tourism development, we received quite a few negative responses. Due to the lack of knowledge of the mentioned plan, we can identify the reasons for no coordination in the answers of the so-called diplomats on the ground and services that work on its creation and realization.

Finally, it should be noted that some, first of all European researchers and cultural practitioners, that deal with issues of affirmation of cultural diversity, understand multiculturalism by saying things simply, in recognition of the fact of cultural (ethnic) pluralism and the rights of different social groups (Mesić, 2006). In globalized time, when information is available to everyone, the job is easier for the team, because while citing all of this, it is clear that globalization processes are being triggered.

What is still necessary is a human factor to turn them into our own advantage. (Http://www.dubrovnik.hr/ured_gradonacelnika.php? id $=4312,2012$ ).

\section{LITERATURE}

[1] Analysis of Current Political Situation in Andalucia and Extremadura. Airgram from American Consul Seville, (1964), U.S. Department of State (str. 45-59). Maryland: National Archives, College Park.

[2] BERKOVIĆ, S.(2009).Diplomacija Dubrovačke Republike. Zagreb-Dubrovnik: Urban - Media.

[3] ERLICH, St.V. (1968). U društvu s čovjekom. Zagreb: Naprijed.

[4] HARRIS, R. (2006). Povijest Dubrovnika. Zagreb: Golden marketing-Tehnička knjiga.

[5] JOVIĆ, M. (2011). Perspektive hrvatske diplomacije kroz turizam Dubrovnika, Medijski dijalozi, No 10, vol. 4, Podgorica: Istraživački medijski centar, str. 624-632.

[6] KROES, R. (2010). Tourism and Cold War Diplomacy. Feature review, 14 (8), 558563. 
[7] MESIĆ, M. (2006). Multikulturalizam, Zagreb: Školska knjiga.

[8] R O S E N D O R F, N. M. (2009). Be El Caudillo's Guest: The Franco Regime's Quest for Rehabilitation and Dollars after World War II via the Promotion.U.S. Tourism to Spain, 23 (8), 365- 407.

[9] Strategija hrvatskog turizma, (2003)., Strategija razvoja hrvatskog turizma do 2010. godine. Zagreb: Ministarstvo turizma, 10-45.

[10] VLAHOVIĆ, D. (2003). Maritimna turistička Hrvatska, Split-Zagreb: Ogranak Matice Hrvatske Split.

[11] VUKONIĆ, B.(2010). Turizam budućnost mnogih iluzija. Zagreb: Visoka poslovna škola Utilus, Plejada. http://www.mint.hr/UserDocsImages/Strategij a\%20hrvatskog\%20turizma\%20-

\%20finalna\%20verzija.pdf, pristupljeno 12 . lipnja 2011.

[12] „Gradonačelnik u Ordu na kongresu Asocijacije europskih novinara"u: http://www.dubrovnik.hr/ured_gradonacelnika .php?id=4312, pristupljeno 18. lipnja 2012. 